1 USP - University of São Paulo Ribeirão Preto Medical School, Department of Pathology and Legal Medicine. Ribeirão Preto, São Paulo, Brazil.

${ }^{2}$ USP - University of São Paulo, School of Dentistry of Ribeirão Preto. Ribeirão Preto, São Paulo, Brazil.

${ }^{3}$ UNICAMP - University of Campinas, Piracicaba Dental School, Department of Health Sciences and Pediatric Dentistry. Campinas, São Paulo, Brazil.

${ }^{4}$ USP - University of São Paulo, School of Dentistry of Ribeirão Preto, Department of Stomatology, Public Health and Forensic Dentistry. Ribeirão Preto, São Paulo, Brazil.

Corresponding author: Ricardo Henrique Alves da Silva USP - Faculdade de Odontologia de Ribeirão Preto. Departamento de Estomatologia, Saúde Coletiva e Odontologia Legal. Área de Odontologia Legal. Avenida do Café, s/n, Bairro Monte Alegre, 14040-904, Ribeirão Preto, SP, Brasil. E-mail: ricardohenrique@usp.br

Editor: Dr Altair A. Del Bel Cury

Received: March 24, 2021

Accepted: August 28, 2021

\section{Dental mapractice litigance in the city of São Paulo (SP), Brazil}

\author{
Silmara Pereira de Sousa ${ }^{1,2}$ (D), Bruna Saud Borges ${ }^{1,2}$ (D), \\ Ana Luisa Rezende Machado ${ }^{1,2}$ (D), Giovanna Teixeira \\ Matteussi ${ }^{1,2}$ (D), Paulo Henrique Viana Pinto ${ }^{1,2}$ (D), \\ Larissa Dutra Bittencourt de Oliveira ${ }^{1}$ (D), Rienne Assis \\ Matos $^{2}$ (D), Marcos Vinicius Coltri ${ }^{3}$ (D), Ricardo Henrique \\ Alves da Silva ${ }^{4}$ (D)
}

The relationship between patients and dentists today is more worn and less based on trust, which can lead to high rates of lawsuits related to civil liability and dental malpractice. Aim: verify if there has been an increase in the number of lawsuits related to questioned dental treatments, and against dentists registered in the city of São Paulo (SP), Brazil, from 2012 to 2017. Methods: We outlined an overview based on the list from the São Paulo Council of Dentistry containing 30,238 registered dentists in the city of São Paulo, and searched for lawsuits on the public base of the São Paulo State Court's. Results: The search, after the inclusion and exclusion criteria, found 247 lawsuits, with dental implants as the most involved specialty. The total indemnities requested ranged from $R \$ 227.42$ to $R \$ 937,000.00$, but no indemnity granted exceeded the amount of $\mathrm{R} \$ 100,000.00$. Conclusion: According to the analysis of cases, there is a progressive increase in the number of civil liability lawsuits against dentists involving dental malpractice litigance.

Keywords: Insurance, liability. Forensic dentistry. Patient harm. Jurisprudence. 


\section{Introduction}

With the advent of the Brazilian Code of Consumer Protection, which has provided patients greater knowledge in regards to their rights and easier access to justice, dentists have been increasingly faced with complaints about treatment and/or lack of information in lawsuits?

The dentist's civil liability is defined as the duty to repair damage caused to the patient ${ }^{2}$. The Brazilian Civil Code characterizes an unlawful act and its obligation of reparation can be found in articles 186, "that who, by voluntary action or omission, negligence or recklessness, violates law and causes harm to others, even if exclusively moral, commits an unlawful act"; and 927, "that who, by an unlawful act, causes harm to another, is obliged to repair it"3. Therefore, a civil liability is characterized by the guilty conduct of the professional, damage suffered by the patient, and a causal link between them, thus generating the obligation of pecuniary reparation (material, moral, and/or esthetic damage) ${ }^{4}$.

Once the lawsuit initiates, an impartial professional acting as an expert witness can be appointed by the judge to carry out an examination and prepare a report, which aims to clarify the technical and scientific issues of the case. Moreover, a lawsuit in Brazil can rely on the presence of a technical assistant who can be appointed by any of the parties involved, and who can assist during the lawsuit ${ }^{5}$.

The patient/dentist relationship is classified as a consumption relationship, with the consumer here interpreted as the patient and author of the lawsuit. In these cases, there is a mechanism used to facilitate consumer protection, known as the inversion of the proof onus. Thus, it is not the patient/author who must prove that the dentist is culpable; it is the professional/defendant who is responsible for proving that there was no fault on his/her part during the professional act. In this regard, the Brazilian Code of Consumer Protection article 6 states in relation to consumer rights:

The facilitation of the defense of your rights, including the inversion of the proof onus in your favor in civil lawsuits, when at the discretion of a judge, the claim is credible or when the consumer is dependent, in accordance with the ordinary rules of experience ${ }^{6}$.

Currently, there is an increase in the number of lawsuits against dentists in Brazil, and the most valuable proof for the defense of the professional are the patient's dental records. Among other functions, they may show that the dentist's conduct was based on technical and scientific literature, the patient did not suffer any damage, or that the eventual damage presented by the patient was not related to the dentist's actions or performance? ${ }^{7}$. Therefore, this research aimed to conduct an analysis of civil liability lawsuits against dentists related to dental treatments in the biggest city in Brazil, the city of São Paulo.

\section{Materials and methods}

This research was approved by the Ethics Commission under CAAE (registration number 03381318.1.0000.5419). Data were collected from the list provided by the 
São Paulo Council of Dentistry of São Paulo (CRO-SP) containing the names of 30,238 dentists registered in the city of São Paulo. In addition, the São Paulo State Court's website (www.tjsp.jus.br) was searched for all available court cases in the city of São Paulo. The lawsuit inclusion criteria adopted were: available as full electronic records; involving, as one of the requested parties, the name of at least one dentist present in the mentioned list; related to civil liability in Dentistry regarding the questioning of dental treatments; and started between 2012 and 2017. The year 2012 was selected as the starting point because it was the year that the system of electronic records was implemented in the São Paulo State Court. For the exclusion criteria, the following were listed: lawsuits available only physically (paper documents) or partially electronically; lawsuits that involved only the company providing dental care as a required part; lawsuits that cited names of dentists from the aforementioned list, but were not related to the object of the research (dental treatments); lawsuits for which electronic records were unavailable; lawsuits that did not start within the period between 2012 and 2017.

First of all, it's important to mention that the research couldn't work on more recent years due to the magnitude of the study. The first part was a manual search, including each name on the São Paulo State Court public basis, resulting in 30,238 different quests, and it take around six months, and reached 1325 lawsuits. Then, the second phase was to check each one of the 1325 lawsuits and apply the inclusion and exclusion criteria, and it took more eight months. Finally, with 247 lawsuits selected, it was necessary to read and study the whole documents (in average with more than 300 pages each) to collect the data of this study, and it took more ten months.

After the selection, a full verification of the records was performed, with the following data collected: (1) year the lawsuit began; (2) dental specialty involved; (3) qualification(s) of the prosecuted dentist; (4) whether or not an expert witness was appointed; (5) the expert witness' specialty; (6) whether or not technical assistants for the parties were indicated, and their specialties; (7) amount of compensation requested; and (8) data related to the sentence. In line with the analysis of these data, the specialties of the professionals (dentists as defendants, expert witnesses, and technical assistants) were checked through the public database of CRO-SP and the Brazilian Federal Council of Dentistry (CFO), and it included more than 300 quests in two different data basis.

\section{Results}

From the 247 lawsuits involving dental malpractice litigance that corresponded to the inclusion criteria of the study, it was observed an increase over the years (Figure 1). 


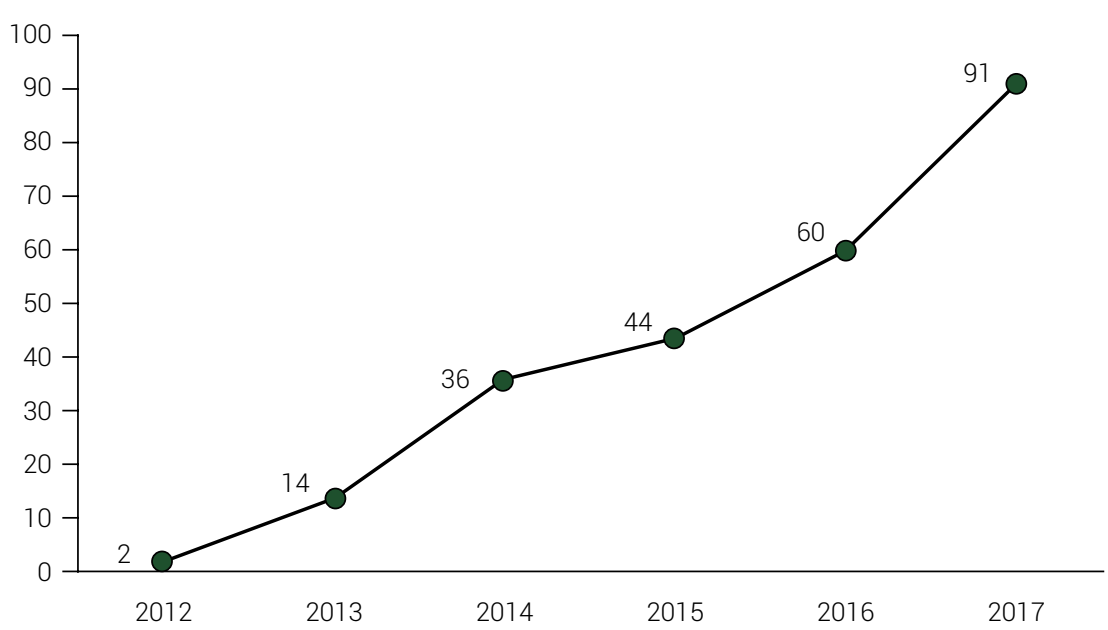

Figure 1. Number of lawsuits against dentists involving dental malpractice litigance, 2012-2017, São Paulo, SP, Brazil.

Figure 2 shows the five most cited dental specialties in the analyzed lawsuits. It is important to note that these specialties refer to the procedures claimed by the patient's request within the lawsuits. Thus, we have related the procedures to existing specialties within Dentistry to better illustrate the results. Some of the lawsuits mentioned more than one procedure. Additionally, while $60 \%(n=149)$ of the lawsuits mentioned referred to procedures related to a single specialty, $27 \%(n=67)$ mentioned two distinct specialties, $11 \%(n=27)$ cited three specialties, and $2 \%(n=4)$ linked to four specialties. Thus, the number of specialties cited exceeds the number of cases found.

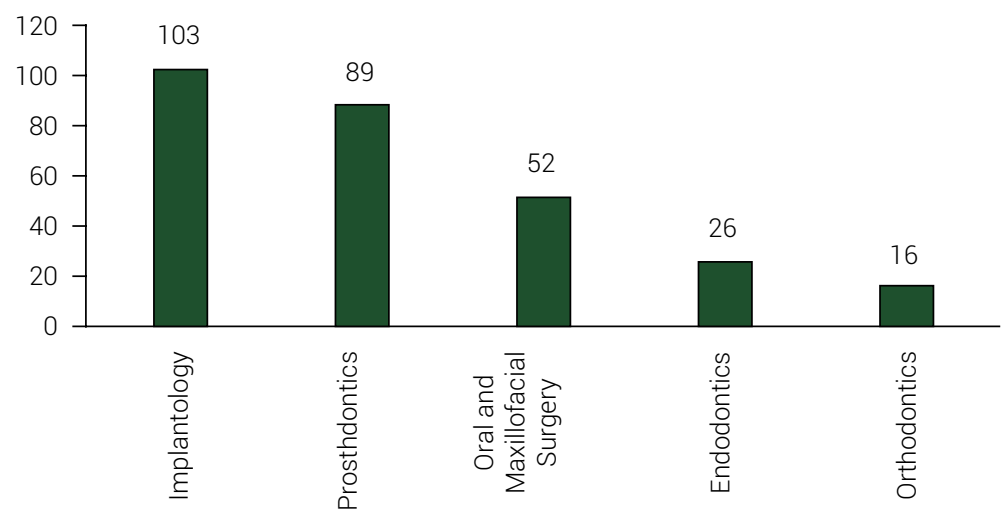

Figure 2. Dental specialties in lawsuits against dentists involving dental malpractice litigance, 2012-2017, São Paulo, SP, Brazil.

The qualification of the dentists involved in the lawsuits were also investigated; $60 \%$ $(n=149)$ of the cases dealt with professionals who had no registered specialty at the time of data collection, while $40 \%(n=98)$ dealt with dentists with a registered specialist title, 31 of whom claimed more than one specialty. The registered specialties are detailed in Figure 3. 


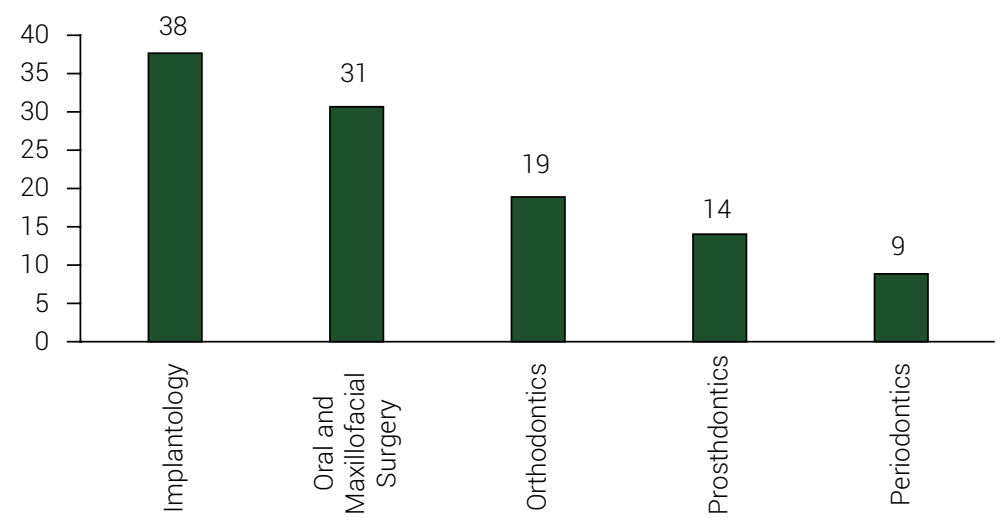

Figure 3. Dentists' specialties in lawsuits against dentists involving the questioning of dental treatments, 2012-2017, São Paulo, SP, Brazil.

Regarding the data collected on expert witnesses, in $12 \%(n=29)$ of the lawsuits, no expert witness was appointed. In $65 \%(n=161)$ of the lawsuits, an expert witness was appointed. In the remaining $23 \%$ of lawsuits, it was not possible to determine expert witness appointment, as cases had not reached this legal phase at time of the data collection. In the lawsuits where an expert witness was appointed, $71 \%(n=115)$ were specialized dentists, of which $61 \%(n=70)$ had one specialty, $37 \%(n=43)$ had two specialties, and $2 \%(n=2)$ of the expert examinations were performed by medical doctors. In addition, among the appointed expert witness, 63\% $(n=72)$ were registered as Forensic Dentistry specialists (Figure 4).

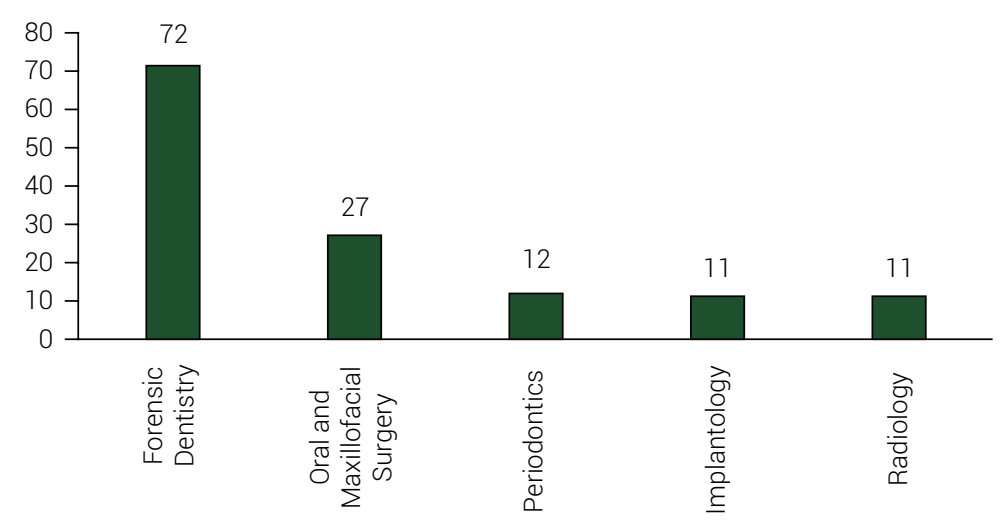

Figure 4. Specialties of expert witnesses appointed in lawsuits against dentists involving dental malpractice litigance, 2012-2017, São Paulo, SP, Brazil.

Regarding the 161 lawsuits that appointed an expert witness, 68\% ( $n=110)$ of these included indications of technical assistants, with $9 \%(n=10)$ of the indications made only by the requesting part, 63\% ( $n=69)$ only by the requested part, and $28 \%(n=31)$ by both parties. Regarding question formulations, they were present in $84 \%(n=136)$, with $7 \%(n=10)$ being performed only by the requesting part, $21 \%(n=29)$ only by the requested part and $71 \%(\mathrm{n}=97)$ by both parties. 
Regarding the 161 cases that appointed an expert witness, two of them experienced conciliation of the parties before the expert examination, and two other cases did not present the report for different reasons. One lawsuit was suspended before they could give the report, and in three other lawsuits, it was not possible to identify the reason for the absence of the report. Additionally, in 51 lawsuits, the reports had not been presented yet due to the phase of the lawsuit at the time of this research. This resulted in 102 cases in which there was presentation of the expert report. Of these, $48 \%(n=49)$ indicated the presence of causal link and $52 \%(n=53)$ indicated the absence of a causal link.

Regarding sentencing data from the 247 included lawsuits, 64\% ( $n=158)$ had not yet reached the sentence stage, $0.4 \%(n=1)$ were suspended and $36 \%(n=88)$ had sentences. From the 88 lawsuits that already had a sentence, 52\% $(n=46)$ were valid and 25\% ( $n=22)$ unfounded; for 23\% $(n=20)$, were extinguished. Thus, regarding indemnities clamed, total amounts ranged between R\$ 227.42 (USD 40.74) and R\$ 937,000.00 (USD 167,860.98); ${ }^{8}$; however, the sentences did not bring amounts higher than R\$100,000.00 (USD 17,914.72) ${ }^{8}$. The study demonstrated that in many lawsuits, there was a distinction between material, moral, and esthetic damages (Table 1).

Table 1. Damages requested and sentenced in lawsuits against dentists involving dental malpractice litigance, 2012-2017, São Paulo, SP, Brazil.

\begin{tabular}{|c|c|c|c|c|c|c|}
\hline \multirow{2}{*}{ Damage } & \multicolumn{3}{|c|}{ Requested indemnities } & \multicolumn{3}{|c|}{ Sentenced indemnities } \\
\hline & Min. & Average & Max. & Min. & Average & Max. \\
\hline Material & $\begin{array}{l}\mathrm{R} \$ 200.00 \\
\text { (USD 35.82) }\end{array}$ & $\begin{array}{l}\text { R\$16,862.90 } \\
\text { (USD 3,020.94) }\end{array}$ & $\begin{array}{c}\mathrm{R} \$ 386,120.00 \\
\text { (USD 69,172.33) }\end{array}$ & $\begin{array}{l}\mathrm{R} \$ 200.00 \\
\text { (USD 35.82) }\end{array}$ & $\begin{array}{c}\mathrm{R} \$ 9,860.48 \\
\text { (USD } 1,766.47)\end{array}$ & $\begin{array}{l}\mathrm{R} \$ 48,266.00 \\
\text { (USD 8,646.72) }\end{array}$ \\
\hline Moral & $\begin{array}{l}\mathrm{R} \$ 1,000.00 \\
\text { (USD 179.14) }\end{array}$ & $\begin{array}{c}\mathrm{R} \$ 46,030.51 \\
\text { (USD 8,246.23) }\end{array}$ & $\begin{array}{c}\mathrm{R} \$ 500,000.00 \\
\text { (USD 89,573.62) }\end{array}$ & $\begin{array}{l}\mathrm{R} \$ 1,000.00 \\
\text { (USD 179.14) }\end{array}$ & $\begin{array}{l}\mathrm{R} \$ 15,323.76 \\
\text { (USD 2,745.20) }\end{array}$ & $\begin{array}{l}\mathrm{R} \$ 100,000.00 \\
\text { (USD 17,914.72) }\end{array}$ \\
\hline Esthetic & $\begin{array}{l}\mathrm{R} \$ 1,350.00 \\
\text { (USD 241.84) }\end{array}$ & $\begin{array}{l}\mathrm{R} \$ 44,932.52 \\
\text { (USD 8,049.53) }\end{array}$ & $\begin{array}{l}\mathrm{R} \$ 210,000.00 \\
\text { (USD 37,620.92) }\end{array}$ & $\begin{array}{c}\mathrm{R} \$ 5,000.00 \\
\text { (USD 37,620.92) }\end{array}$ & $\begin{array}{l}\mathrm{R} \$ 18,500.00 \\
\text { (USD 3,314.22) }\end{array}$ & $\begin{array}{l}\mathrm{R} \$ 40,000.00 \\
\text { (USD 7,165.89) }\end{array}$ \\
\hline Total & $\begin{array}{l}\mathrm{R} \$ 227.42 \\
\text { (USD 40.74) }\end{array}$ & $\begin{array}{c}\mathrm{R} \$ 67,636.71 \\
\text { (USD 12,116.93) }\end{array}$ & $\begin{array}{c}\mathrm{R} \$ 937,000.00 \\
\text { (USD 167,860.98) }\end{array}$ & $\begin{array}{c}\mathrm{R} \$ 850.00 \\
\text { (USD 152.27) }\end{array}$ & $\begin{array}{l}\mathrm{R} \$ 20,861.18 \\
\text { (USD 3,737.22) }\end{array}$ & $\begin{array}{c}\mathrm{R} \$ 100,000.00 \\
\text { (USD 17,914.72) }\end{array}$ \\
\hline
\end{tabular}

\section{Discussion}

No professional is exempt from making mistakes, and this awareness is the first step to combat possible professional weaknesses in the face of processes related to civil liability. Therefore, certain conduct is essential in preventing or minimizing the chances of possible lawsuits, such as maintaining a harmonious relationship with the patient, producing well-organized dental records, providing all the information to the patient as often as possible, and continuous monitoring of the patient ${ }^{9}$. In Brazil, the dentist's civil liability is guided by the Civil Code and the Code of Consumer Protection. These codes assure the patient that it is the professional's duty to act with caution in the practice of dentistry? 
To begin discussion of the analysis of this research we will highlight the limitations inherent to the data collection. The analyzed period was decided based on the beginning of the implementation of the electronic lawsuit records by the São Paulo State Court, since these can be fully accessed, unlike "paper" lawsuits that only have some or no information available online. It would be logistically impossible to analyze physical records one by one, justifying the methodological option of considering only electronic lawsuits in order to obtain more complete and real data. Because of this, it is possible that the low number of lawsuits in the initial years was due to the ongoing implementation of this new form of producing and filing of court records.

Another limitation is the dependence on a list of registered professionals, which does not follow a historical series, meaning if any professional requested a transference or cancellation of their registration before the time of this research, it is not possible to have information on this record, which them limits the search for their respective lawsuits. Finally, there is a time lag between the data presented in the study and its publication, as the achievement of these results required the nominal and individual search of each of the 30,238 names on the list available manually, that is, in 2018 each of the full names of registered Dentists were inserted one by one on the platform of the São Paulo State Court's website, followed by a full reading of the records of the cases found, and tabulation of data, one must take into account the great time demand of this process since it does not allow automation. In the following year, the detailed data analysis of each civil liability lawsuit was carried out, configuring a cross-sectional analysis.

However, despite these limitations, this study was able for the first time to draw a design of civil lawsuits against dentists in the city of São Paulo in the first instance court, regarding questioning the dental treatments. This followed an increasing curve over the years, which reaffirms the trend observed in other cities and regions throughout Brazil 170,11 . The analysis found a continuous annual increase in lawsuits, with the final year, 2017, responsible for $36.8 \%$ of the total litigations analyzed.

Such an increase can be due to a number of factors, such as a constant increase in the number of dentists, the rise in law professionals specializing in health, competition among dentists and dental companies, and changes in the professional-patient relationship over the years ${ }^{10,12}$. This relationship was previously based solely on trust, with the professional being the one who was knowledgeable and made decisions; today, however, the patient has easier access to knowledge about his contractual situation, and has become more demanding of information regarding the services provided ${ }^{10}$.

Melani et al. $^{13}$ (2010) demonstrated this problem by showing that about $29 \%$ of the lawsuits analyzed in their study resulted from unwanted care in the face of dissatisfaction or doubt, concluding that the lack of communication and clarification resulted in a serious problem in the professional-patient relationship, often resulting in a breach of trust. Additionally, there is a social appeal in searching for monetary compensation from dental damages, often encouraging the patient to resort to the judicial system ${ }^{5}$. 
Another point to discuss is that health care practitioners who experience fatigue, overwork, and stress may be more likely to commit an error ${ }^{14-16}$, which increases the susceptibility of being involved in a civil liability lawsuit. Nowadays, several reports maintain that dentistry is an exceedingly stressful profession where distress and eventual burnout are distinct possibilities ${ }^{17}$. Yansane et al. ${ }^{18}$ (2020), evaluated the relationship between burnout, work engagement, and self-reported dental errors among Northamerican dentists and of the 391 responding dentists, 46.1\% reported concern that they had made a dental error in the last 6 months, $12.1 \%$ of the dentists were informed by dental staff that they may have committed an error in the last six months, 16\% were concerned that a malpractice lawsuit would be filed against them, and $3.6 \%$ were actively involved in a malpractice lawsuit.

Dental treatments often seemed related to the specialties of dental implants, prosthodontics, oral and maxillofacial surgery, endodontics, and orthodontics, confirming the results obtained in the Londrina population ${ }^{1}$ and, previously, in general research conducted in the national territory ${ }^{10}$. Some of these specialties seem to be common, even when evaluated in different regions or time frames, as in the studies by Magalhães et al. ${ }^{19}$ (2019), where the most involved specialties were, in decreasing order, prosthodontics, orthodontics, and dental implants, and Rosa et al. ${ }^{20}$ (2012), where the specialties remained the same, but in reverse order. This scenario is repeated even internationally, where Thavajanah et al. ${ }^{21}$ (2019) found that the treatments that led to a lawsuit most often in India were tooth extraction, root canal treatment and implants, and in Rome, the authors found a similar perspective where the most litigious dental activities was prosthetic, implantology and endodontia ${ }^{22}$. This phenomenon can be explained by the consideration that these procedures take a longer time to complete, are usually more costly, and bring a greater esthetic appeal and, therefore, create a greater expectation by the patient. This, many times, can be encouraged by the dentist's advertisements, which assigns to the dentist an obligation of result, where they must reach a certain goal desired by the patient ${ }^{5,7}$.

As previously mentioned, we observed that $60 \%$ of the professionals involved in litigation did not have a registered specialty. According to Brazil Law number 5.081/1966, dentists are allowed to "perform all acts related to the dentistry field, resulting from knowledge acquired from undergraduate and graduate courses"23. However, having the necessary professional legal qualification does not mean having the ability to perform all the procedures the degree confers, and it is necessary to be aware of the limits of one's competence, always bearing in mind the responsibility and legal consequences regarding all professional acts performed ${ }^{1,24}$.

Comparing the research by Lino Junior. et al. ${ }^{1}$ (2017), where only $7.18 \%$ of individuals had a registered specialty, to our study, where $40 \%$ of the professionals had such qualifications, we can consider the difference to be related to distinct geographic location and population demands that required a more generalist approach by the professionals, as in the case of the first study mentioned, and a more specialized approach, as in the case of the present study. Therefore, despite the high number of dentists without a specialist title registered, it is not possible to state that they do not have the capacity to carry out the dental treatments. 
We found that in $65 \%$ of the cases an expert witness was appointed, and meaningful results were found by Zanin et al. ${ }^{12}$ (2015), where $84.2 \%$ of cases involved an expert witness, and Montagna et al. ${ }^{25}$ (2008), where $73.1 \%$ of cases involved an expert witness. This highlights the importance of the expert as a clarifying agent for technical and scientific issues, who will produce impartial evidence to the judge and the related parties $^{13}$. On the other hand, the study by Magalhães et al. ${ }^{19}$ (2019) observed that expert reports were only used in $3.9 \%$ of the assessed lawsuits ${ }^{20}$.

Of the appointed expert witnesses, 115 had some registered specialty, and we observed that Forensic Dentistry as a specialty that goes side-by-side with law. For Silva $^{9}$ (2010), the expert examination cannot be performed by just any professional in the field (here referring to dental treatment), since it is not enough just to be his or her profession, but requires a professional qualified and specialized in a specific area, especially with the expert routine that is part of the scope of the forensic dentistry specialty. In this research, $63 \%$ of expert witnesses were registered as forensic dentistry specialists.

In the lawsuits with an appointed expert witness, we found that in $68 \%$ of these cases, a technical assistant (often referred to as "part's expert witness") was hired. Compare this to the data found by Zanin et al. ${ }^{12}$ (2015), in which only $10.3 \%$ of the parts involved in the lawsuits indicated hiring these professionals, even though more than $80 \%$ of the lawsuits involved expertise examination. This increase in hiring of technical assistants over the years denotes a greater awareness on the importance of these professionals in the lawsuit. The importance of such a service during a lawsuit is justified by the guarantee of the technical adversary, that is, the partiality to the part that hired the service. The technical assistant can assist the lawyer in formulating questions, focusing on technical matters, limiting and guiding the parameters followed by the expert examination, and participate in due diligence regarding the expert examination. Technical assistants can also prepare an independent opinion that may agree with, complement, or even refute the report issued by the appointed expert witness. $(5,12)$.

When comparing the number of lawsuits in which at least one of the parts indicated a professional as a technical assistant and those in which questions to expert witness were submitted, it is clear that there are more lawsuits with questions presented than those with designated technical assistants. This is due to the fact that the elaboration of the questions is not strictly linked to the presence of technical assistants, and it can be done by the part itself, by the lawyer, or even by the court. The questions work as a device to try to prove the allegations made in the initial petition (by the author/patient) or in the defense (by the required/dentist) ${ }^{5,26}$. For this reason, it is worth reflecting the usefulness of a professional, who has not only the technical and scientific knowledge of the areas involved, but also the expertise in knowing which points are worth highlighting, with ethics, in favor of the client.

When instituted, an indemnity action aims to make reparation to the victim to compensate any damage suffered by the patient when the causal nexus inherent to the dental treatment and the professional conduct are proven. Often, indemnity is subdivided into material and moral damage, and more recently, esthetic damage. When it comes to valuing the material damage, there are not many difficulties, considering 
that it is enough to have proof of the equity losses by the requesting part ${ }^{1,27}$. With regard to moral damage, subjectivity and psychological effects make determination complex, and the judge must use subjective criteria for its definition, using proportionality and reasonableness, as the objective of the indemnity is not enrichment, but the reparation of unfair suffering ${ }^{28}$. The same reasoning applies to the arbitration of any compensation for esthetic damage.

In this study, the most varied claims were collected, ranging from $\mathrm{R} \$ 227.42$ (USD 40.74) to R\$ 937,000.00 (USD 167,860.98) ${ }^{8}$. However, there was a tendency for the sentence, when the lawsuit was deemed valid, to impose condemnatory amounts lower than that requested in the initial petition, not exceeding $R \$ 100,000.00$ $\left(\right.$ USD 17,914.72) ${ }^{8}$. The same seens to occours in India, where Thavarajah et al. ${ }^{21}$ (2019) found the average compensation claimed as INR 5,772.87 (USD 78,36) ${ }^{8} \pm 9,058.98$ (USD 122.96) ${ }^{8}$ while the average compensation awarded was 1,039.98 (USD 14.11)8. The data obtained in this research are in line with information provided in other studies, given that the research points to a discrepancy between the values pleaded and the condemnations set out in the sentences ${ }^{1,29,30}$.

The number of lawsuits involving dental malpractice litigance in the city of São Paulo (SP), Brazil, has grown progressively over the years, and the dental treatments claimed often seemed related to the specialties of dental implants, prosthodontics, oral and maxillofacial surgery, endodontics, and orthodontics. This rases an alert for dentists to use their technical and scientific knowledge in conjunction with current ethics and legislation.

\section{ACKNOWLEDGEMENTS}

Own funding.

\section{References}

1. Lino-Junior HL, Terada ASSD, Silva RHA, Soltoski MPC. [Civil liability lawstuits in dentistry, Londrina, Brazil]. Rev Jurid. 2017;1(46):515-31. Portuguese. doi: 10.21902/revistajur.2316-753X.v1i46.2261.

2. Figueira Junior E, Trindade GO. [Responsibility of the surgeon dentist accord to the Code of Defense of the Consumer]. Cad UniFOA. 2010 Mar;5(12):63-70. Portuguese. doi: 10.47385/cadunifoa.v5i12.1006.

3. Presidency of the Republic of Brazil. [Law n. 10,406, 2002 January 10. Establishes the Civil]. Diario Oficial União. 2002 [cited 2020 Feb 30] Available from: http://www.planalto.gov.br/ccivil_03/leis/2002/I10406.htm. Portuguese.

4. Medeiros UV, Coltri AR. [Civil responsibility of the dentist]. Rev Bras Odontol, 2014;71(1):10-6. Portuguese.

5. Silva RHA, Musse JO, Melani RFH, Oliveira RN. [Surgeon dentist's civil liability: the technical assistant's importance]. Rev Dent Press Ortod Ortop Facial. 2009;14(6):65-71. Portuguese. doi: 10.1590/S1415-54192009000600009.

6. Presidency of the Republic of Brazil. [Law n. 8,078, 1990 September 11. [Provides for consumer protection and other measures]. Diario Oficial União. 1990 [cited 2020 Feb 30] Available from: http://www.planalto.gov.br/ccivil_03/leis//8078.htm. Portuguese. 
7. Kato MT, Goya S, Peres SHCS, Peres AS, Bastos JRM. [Civil liability of dentist]. Rev odontol Univ Cidade Sao Paulo. 2018;20(1):66-75. Portuguese. doi: 10.26843/ro_unicid.v20i1.610.

8. Central Bank of Brazil. Homepage. [cited 2020 oct 22]. Available from: https://www.bcb.gov.br/en

9. Silva RHA. [Professional guidance for dentists: ethics and legislation]. São Paulo: Santos; 2010. Portuguese.

10. Lima RBWE, Moreira VG, Cardoso, AMR, Nunes FM, Rabello PM, Santiago BM. [Jurisprudence' Survey of Civil Liability Cases Against Dentistsin Brazilian Courts of Justice]. Rev Bras Cienc Saude. 2012;16(1):49-58. Portuguese. doi: 10.4034/RBCS.2012.16.01.08.

11. Paula FJ, Motta MV, Bersácola RN, Muñoz DR. [Scenario of civil liability actions against dentists in Brazilian courts]. Rev Paul Odontol. 2010;32(4):22-8. Portuguese.

12. Zanin AA, Strapsson RAP, Melani RFH. [Jurisprudential study: evidences in dental civil liability lawsuit]. Rev Assoc Paul Cir Dent. 2015;69(2):119-27. Portuguese.

13. Melani RFH; Oliveira RN, Tedeshi-Oliveira SV, Juhás R. Legal devices and arguments mostly used in civil lawsuits: casuistry analysis in Dentistry. RPG Rev Pós-Grad. 2010;17(1):46-53. Portuguese.

14. Shanafelt TD, Balch CM, Bechamps G, Russell T, Dyrbye L, Satele D, et al. Burnout and medical errors among American surgeons. Ann Surg. 2010 Jun;251(6):995-1000. doi: 10.1097/SLA.0b013e3181bfdab3.

15. Leape LL. Error in medicine. JAMA. 1994 Dec;272(23):1851-7. doi: 10.1001/jama.1994.03520230061039.

16. Leape LL, Berwick DM, Bates DW. What practices will most improve safety? Evidence-based medicine meets patient safety. JAMA. 2002 Jul;288(4):501-7. doi: 10.1001/jama.288.4.501.

17. Gorter RC, Eijkman MA, Hoogstraten J. A career counseling program for dentists: effects on burnout. Patient Educ Couns. 2001 Apr;43(1):23-30. doi: 10.1016/s0738-3991(00)00141-5.

18. Yansane A, Tokede O, Walji M, Obadan-Udoh E, Riedy C, White J, et al. Burnout, Engagement, and Dental Errors Among U.S. Dentists. J Patient Saf. 2020 Apr 3. doi: 10.1097/PTS.0000000000000673.

19. Magalhães LV, Costa B, Silva RHA. [Analysis of the lawsutisinvolving Dentistry in metropolitan Vitória, Espírito SantoState, brazil]. Rev Bras Odontol Leg RBOL. 2019;6(2):13-20. Portuguese. doi: 10.21117/rbol.v6i2.232.

20. Rosa FM, Fernandes MM, Daruge-Júnior E, Paranhos LR. [Material and moral damages in cases involving dentists in the state of São Paulo]. RFO. 2012;17(1):26-30. Portuguese. doi: 10.5335/rfo.v17i1.2537.

21. Thavarajah R, Saranya V, Priya B. The Indian dental litigation landscape: An analysis of judgments on dental negligence claims in Indian Consumer Redressal Forums. J Forensic Leg Med. 2019 Nov;68:101863. doi: 10.1016/j.jflm.2019.101863.

22. Manca R, Bruti V, Napoletano S, Marinelli E. A 15 years survey for dental malpractice claims in Rome, Italy. J Forensic Leg Med. 2018 Aug;58:74-7. doi: 10.1016/j.jflm.2018.05.005.

23. Presidency of the Republic of Brazil. [Law n. 5,081, 1966 August 24. [Regulates the Practice of Dentistry.]. Diario Oficial União. 1966 [cited 2020 Feb 30] Available from: https://presrepublica.jusbrasil.com.br/legislacao/128600/lei-5081-66. Portuguese.

24. Lino-Júnior HL, Gabriel M, Daruge-Júnior E, Silva RHA. [Forensic Dentistry education in Brazil: an invitation to reflection]. Rev Abeno. 2015;15(2):38-46. Portuguese.

25. Montagna F, Manfredini D, Nuzzolese E. Professional liability and structure of litigation in dentistry. Minerva Stomatol. 2008 Jul-Aug;57(7-8):349-57.

26. Sarmento MS, Dezem TU, Medeiros UV. [The importance of the dentistry expert in lawsuits]. Rev Bras Crimin. 2018;7(3):44-52. Portuguese. doi: 10.15260/rbc.v7i3.231. 
27. Giostri HT. [Ethical civil liability of dentists: a new vision]. Curitiba: Juruá; 2012. Portuguese.

28. Presidency of the Republic of Brazil. [Constitution of the Federative Republic of Brazil, 1988]. 1988 [cited 2020 Feb 30] Available from:

http://www.planalto.gov.br/ccivil_03/constituicao/constituicao.htm. Portuguese.

29. Bouchardet FCH, Vieira SLG, Miranda GE, Fernandes MM, Vieira DNP, Silva RF. [Assessment of the aesthetic damage in the jurisprudence of the Court of Justice, Minas Gerais]. ROBRAC. 2013;22(63):116-9. Portuguese. doi: 10.36065/robrac.v22i63.820.

30. Terada ASSD, Araujo LG, Flores MRP, Silva RHA. [Civil Liability of Dental Surgeon: Legal Proceedings Analysis in the City of Ribeirao Preto, São Paulo State, Brazil]. Int J Odontostomat. 2014; 8(3), 365-369. Spanish. doi: 10.4067/S0718-381X2014000300008. 